\title{
Use of rice husk for emission neutral energy generation and synthesis of solar-grade silicon feedstock
}

K. K. Larbi, R. Roy, M. Barati, V. I. Lakshmanan, R. Sridhar and A. McLean

Version Post-print/Accepted Manuscript

Citation Larbi, K.K., Roy, R., Barati, M. et al. Biomass Conv. Bioref. (2012) 2:

(published version) 149. https://doi.org/10.1007/s13399-012-0034-6

Publisher's statement This is a post-peer-review, pre-copyedit version of an article published in Biomass Conversion and Biorefinery. The final authenticated version is available online at: http://dx.doi.org/10.1007/s13399-012-0034-6

How to cite TSpace items

Always cite the published version, so the author(s) will receive recognition through services that track citation counts, e.g. Scopus. If you need to cite the page number of the author manuscript from TSpace because you cannot access the published version, then cite the TSpace version in addition to the published version using the permanent URI (handle) found on the record page.

This article was made openly accessible by $U$ of $T$ Faculty. Please tell us how this access benefits you. Your story matters. 


\section{Use of Rice Husk for Emission Neutral Energy Generation and Synthesis of Solar Grade Silicon Feedstock}

K. K. Larbi(1), R. $\operatorname{Roy}^{(2)}$, M. Barati(3*), V.I. Lakshmanan(4), R. Sridhar(4), A. McLean ${ }^{(5)}$

1) Formerly graduate student at the University of Toronto, currently with ARISE Technologies Co., Waterloo, Canada

2) Research Associate, University of Toronto, Toronto, Canada

3*) Corresponding author

Assistant professor, University of Toronto, Dept. of Materials Science and Engineering

140 - 184 College Street, Toronto, ON

Canada M5S 3E4

Tel: $\quad$ (416) $978-5637$

Fax: (416) $978-4155$

Email: mansoor.barati@utoronto.ca

4) Process Research Ortech Inc., Mississauga, Ontario, Canada

5) Professor Emeritus, University of Toronto, Dept. of Materials Science and Engineering 


\begin{abstract}
$\underline{\text { Abstract }}$
The potential use of rice husk as a source of energy and also for producing high purity silicon has been investigated by a combination of pilot trials, theoretical calculations and laboratory experiments. Rice husk was combusted at $850{ }^{\circ} \mathrm{C}$. Mass balance together with the pilot results indicates an electricity generation potential of $1 \mathrm{MWh}$ per tonne rice husk. The process also generates $180 \mathrm{~kg}$ rice husk ash (RHA) that is used for production of high purity silicon through a hybrid pyrometallurgical-hydrometallurgical process. The process consists of three major steps; purification of RHA by leaching and roasting, reduction by magnesium, and recovery of silicon through two steps of leaching. The silicon generation process steps were optimized, showing that about $85 \%$ of silicon in the RHA can be recovered. The silicon product has a total impurity of $<0.7 \%$, hence it may be used as a suitable feedstock for production of solar grade silicon.
\end{abstract}

\title{
Keywords
}

Rice husk, Bioenergy, Biomass combustion, Rice husk ash, Silicon 


\section{Introduction}

Today's global energy mix is largely dominated by fossil based fuels. However, with ever increasing concerns over energy related climate change and the unsustainable nature of fossil fuels exploitation, the need for innovative renewable energy alternatives has been receiving considerable attention in recent years. Renewable energy alternatives from solar photovoltaic's, wind and biomass resources are considered promising due to their environmental friendliness and sustainability. At present, solar photovoltaic power production technology is much dependent on silicon material of the requisite purity [1] whilst biomass sources for conversion to energy are mainly from crop residue as well as waste by-products of crop and wood processing [2].

Rice husk is a typical agricultural waste from rice milling that constitutes between 14-27\% of the weight of rice paddy [3] with average being about $20 \%$ [4]. In 2008, the world rice paddy production was 685 million tonnes [5]. This is equivalent to approximately 137 million tonnes of rice

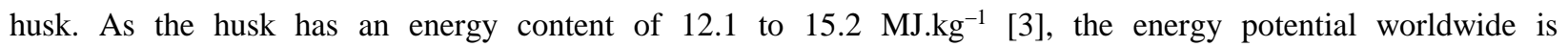
around 1.7 to $2.1 \mathrm{EJ} \cdot \mathrm{y}^{-1}$.

Direct combustion and gasification are the current technologies to generate electricity from rice husk. Rice Husk Ash (RHA), the solid residue of such processes has found application as pozzolan in the cement and concrete as well as an insulator in the steel industry [6]. However, only a small fraction of the nearly $20 \%$ ash content from rice husk combustion has commercial usefulness. This is primarily because in almost all of the existing installations, the produced ash contains about 80-95\% silica [7], in the form of cristobalite, which is a known carcinogen. The formation to crystalline silica is due to high processing temperature and/or long reaction time. Utilizing the energy value of rice husk thus presents a disposal challenge for ash and an environmental nuisance.

As opposed to most of the current energy generation technologies that do not control temperature well and allow the ash to remain at high temperatures for a relatively long residence period, the Toroidal Bed (TORBED) reactor utilizes a unique configuration to complete the combustion of husk in a short time at a precisely controlled temperature. This results in zero or at most trace quantities of cristobalite. TORBED reactors possess several advantages such as smaller reactor size, more thorough processing due to the improved particle movement, flexible operation, and easy start-up and shut down as compared to conventional fluidized beds [8]. These novel gas/solid reactors are used for processing a wide range of materials [9-12]. Rapid heat and mass transfer from the gas phase to the solids are achieved in these reactors [13, 14]. The unique features of the TORBED reactor present the possibility of generating both energy from the combustion and producing an ash that can be safely treated. With the high amount of silica -the raw material from which silicon is produced- and a relatively low and narrow range of metallic impurities than quartzite rocks used in the conventional carbothemic process of silicon production [15], the ash from rice husk could be an attractive and renewable source of raw material for high purity silicon production. 
Although the feasibility of producing silicon from RHA was attempted in the 1980's by a few research groups [16-19], no established process with optimized conditions was developed. This paper therefore presents and discusses an integrated process with some optimized conditions for generating energy from rice husks and producing high purity silicon for possible use as solar grade silicon feedstock. The analysis of recoverable energy from rice husk combustion that can be applied to meet part of the silicon production energy requirement is also presented.

\section{Energy generation from rice husk}

Rice husk of Indian origin was obtained and processed at pilot plant facility of Process Research Ortech, using a TORBED EBR (expanded bed reactor). The ultimate analysis of the rice husk used in this research is provided in Table 1.

\section{Table 1- Ultimate analysis of rice husk}

The basic parameters obtained in the pilot trials were used to perform energy and mass balance calculations. For the purpose of calculation of energy release from combustion, the combustible material is considered to be cellulose $\left(\mathrm{C}_{6} \mathrm{H}_{10} \mathrm{O}_{5}\right)$, noting that the atomic ratio of $\mathrm{C} / \mathrm{H}$ in the rice husk is 0.59 , very close to the stoichiometry ratio of 0.6 in cellulose. A process flow diagram for production of amorphous rice husk ash and steam is shown in Fig. 1. As seen, the rice is combusted with air in a TORBED reactor. The mass ratio of air to rice husk is kept at around $14-15: 1$. For a reactor processing $1000 \mathrm{~kg} \cdot \mathrm{h}^{-1}$ of rice husk, about $180 \mathrm{~kg}$ of ash and $15,300 \mathrm{~kg}$ off-gas is generated based on the pilot trials and mass balance calculations (Tables 2 and 3).

\section{Table 2- Mass balance for combustion of one tonne per hour rice husk, in a TORBED reactor}

The off-gas leaves the reactor along with the ash at a temperature about $850{ }^{\circ} \mathrm{C}$. The volumetric flow out of the TORBED EBR entering the boiler at $830{ }^{\circ} \mathrm{C}$ is $47,835 \mathrm{~m}^{3} \cdot \mathrm{h}^{-1}$ and assuming that the exit from the boiler is at $150{ }^{\circ} \mathrm{C}$, the volumetric flow entering the bag house is $18,350 \mathrm{~m}^{3} \mathrm{~h}^{-1}$. The exit gas from the TORBED EBR has an energy content of $14 \mathrm{GJ} . \mathrm{h}^{-1}$ and a heat capacity of $1.5 \mathrm{~kJ} \cdot \mathrm{kg}^{-1} \cdot{ }^{\circ} \mathrm{C}^{-1}$ plus $0.11 \mathrm{GJ}^{-1} \mathrm{~h}^{-1}$ of energy contained in the ash for a total of $14.11 \mathrm{GJ}^{-1}$. By cooling the off-gas to $150{ }^{\circ} \mathrm{C}$, the boiler will have an output of about $11 \mathrm{GJ} \cdot \mathrm{h}^{-1}$, representing a boiler efficiency of $78 \%$. With a typical conversion efficiency of $33 \%$ for steam energy to electricity, this is equivalent to a $1 \mathrm{MWe}$ power plant. In other word, the electricity equivalent of the rice husks is $1 \mathrm{MWh} \cdot \mathrm{t}^{-1}$.

Fig. 1

Table 3- Exhaust gas composition and flowrate 


\section{Recovery of high purity silicon from rice husk ash}

The overall scheme of experimental approach to recover silicon from the rice husk ash followed throughout this work is illustrated in Fig. 2. Essentially, the process consists of three major steps: purification of RHA by roasting and leaching, metallothermic reduction of RHA silica by magnesium, and recovery of silicon from the reduction products. Prior to purification of the RHA from the TORBED reactor in this study, the physico-chemical properties of the RHA were determined by various analytical techniques; the particle size distribution was determined with a laser diffraction particle size analyser (Malvern Master Sizer S). The chemical composition was determined by a combination of ICP-MS and Leco carbon analyser. The specific surface area of the as-received RHA was determined using Coulter SA 3100 Analyzer with nitrogen as the adsorbate gas and the Brunauer-Emmett-Teller (BET) calculation model [20]. The crystal structure of the RHA, phases in the reduction reaction product and final silicon from the process were identified using Philips X-ray diffractometer (model PW 3710)

\section{Fig. 2}

\subsection{Materials and Methods}

Enrichment of the silica content in the as-produced RHA was carried out by a combination of acid leaching and roasting in air. All leaching solutions were prepared from Caledon trace metal grade (TMG) acid reagent except for the glacial acetic acid which was American Chemical Society (ACS) certified grade. Leaching of the RHA was carried out in a mechanically agitated Teflon beaker $(1 \mathrm{~L})$ at $10 \%$ solids using $10 \%$ by weight $\mathrm{HCl}$ solution. Time and temperature of leaching were respectively varied at 1 and $4 \mathrm{~h}$ and 60 and $90^{\circ} \mathrm{C}$ in order to determine the best leaching condition for optimal impurity removal from the RHA. The leached RHA after thorough rinsing with de-ionized water was dried and roasted in air at two selected temperatures of 500 and $700{ }^{\circ} \mathrm{C}$ for a period of $1-4 \mathrm{~h}$.

The purified $\mathrm{SiO}_{2}$ (RHA) and $\mathrm{Mg}$ granules (98\%, Sigma Aldrich) mixture in predetermined weight ratios were wet blended with $4 \%$ polyvinyl alcohol solution (98-99\%, Fischer) and briefly dried under an argon atmosphere. The dried reactants were uniaxially compacted under pressure of $98.5 \mathrm{MPa}$ into pellets of $16 \mathrm{~mm}$ diameter using a manually operated hydraulic press. The volume compression acehived averaged at $60 \%$.

The reactants were compacted with a view to minimize dusting during handling, increase interfacial contact area of the magnesium - silica particles for reaction, and improve charge through put of the process.

The charge composition was formulated based on pure silica and the overall reaction as shown in Equation (1). The effect of excess magnesium in the starting charge on the reaction product was investigated by varying the amount of excess magnesium in the charge between 0-25\%, where 0\% corresponds to stoichiometry composition. The effect of temperature on the reduction product was also investigated at a fixed $\mathrm{Mg}-\mathrm{SiO}_{2}$ (RHA) composition. The reduction experiments were carried out under 
argon atmosphere at selected temperatures in the range of $600-900^{\circ} \mathrm{C}$. The sample temperature was first raised at the rate of $10{ }^{\circ} \mathrm{C} \cdot \mathrm{min}^{-1}$, held at the target temperature for 1 hour and then allowed to cool to room temperature by switching off the furnace.

$\mathrm{SiO}_{2}(\mathrm{~s})+2 \mathrm{Mg}(\mathrm{s})=\mathrm{Si}(\mathrm{s})+2 \mathrm{MgO} \quad \Delta \mathrm{G}^{\circ}{ }_{298 \mathrm{~K}}=-282 \mathrm{~kJ} / \mathrm{mol}$

A schematic diagram of the reduction set-up is shown in Fig. 3. The equipment consisted of a Lindberg horizontal tube furnace with a recrystallised alumina work tube of inner diameter $54 \mathrm{~mm}$. The temperature was measured using data logger thermometer (Omega HH306A) and a $\mathrm{K}$ type thermocouple that was located close to the charge. The reduction product from each experiment was hand milled using mortar and pestle till 100\% passing Tyler sieve \#. $50(300 \mu \mathrm{m})$. Subsequently, samples were taken and further milled to 'talc powder' fineness for quantitative X-ray diffraction (XRD) analyses using the Reitveld method [21-23].

\section{Fig. 3}

The previously ground reduction product was leached in two stages. Table 4 summarizes the system of leaching reagent considered for the first stage leaching of the finely ground reduction products in order to establish the most effective leachant. Leaching temperature was kept averagely at $70{ }^{\circ} \mathrm{C}$ for 1 $\mathrm{h}$ at solid to liquid ratio of 2 g. $\mathrm{L}^{-1}$ with moderate agitation in each test. The leached residue obtained after vacuum filtration was thoroughly washed with de-ionized water, dried and then subjected to a second stage leaching.

\section{Table 4-Leaching reagent type and effective $\left[\mathrm{H}^{+}\right]$concentration for first stage post reduction leaching}

The reagent for the second stage leaching comprised a mixture of 2.76 mol.L $\mathrm{L}^{-1} \mathrm{HF}$ and 4.38 mol. $\mathrm{L}^{-1} \mathrm{CH}_{3} \mathrm{COOH}$ (acetic acid) in a volume ratio of 1:9 respectively. Leaching temperature was kept averagely at $70{ }^{\circ} \mathrm{C}$ for $1 \mathrm{~h}$ at solid to liquid ratio of 20 g. $\mathrm{L}^{-1}$ with moderate agitation. The residue was dried under purging argon. The final residue from the second stage leaching was subjected to XRD and ICP-MS/OES as previously described.

The powdered residue obtained from the final leaching was uniaxially compacted at room temperature into $2.5 \mathrm{~g}$ disc pellets as described before. The silicon pellets were placed in alumina crucible and inserted in the hot zone of a resistance heating furnace. The furnace and content was argon purged and then heated at $100{ }^{\circ} \mathrm{C} \cdot \mathrm{h}^{-1}$ to a temperature of $1500{ }^{\circ} \mathrm{C}$ where it was maintained for $4 \mathrm{~h}$ before allowing controlled cooling to room temperature. 


\section{Results}

The chemical analyses of the as-received RHA and the purified RHA together with the BET specific surface area, mean particle size and the loss on ignition (LOI) values are given in Table 5. The values under column $\mathrm{I}$ in this table are for the as-received materials and those in column II represent the sample that was leached at $90{ }^{\circ} \mathrm{C}$ for $4 \mathrm{~h}$ and roasted at $700{ }^{\circ} \mathrm{C}$ for a period of $1-2 \mathrm{~h}$. This sample was found to have the lowest total impurities when compared to the other purification conditions that were tested.

\section{Table 5-Characteristics of as-received and purified RHA samples}

Boron and phosphorus are the two most difficult impurities to be removed from metallurgical grade silicon in order to meet specification requirement of silicon for integrated circuit or solar cell fabrications. It can be seen from Table 5 that the purification treatment of the as-produced RHA reduced the boron and phosphorus content by a factor of about 10 and 5 respectively whilst the overall purity of the silica was improved by approximately $8 \%$. The purified RHA had a white appearance as result of burning out of the carbon as per the classification of RHA by Houston [24].

An X-ray diffractogram of the as-produced RHA is given in Fig. 4. The major reflections or peaks of crystalline quartz occur at Bragg $2 \theta$ angles of $20.856^{\circ}, 26.636^{\circ}$ and $36.541^{\circ}$. It can be seen that no defined peaks corresponding to these Bragg $2 \theta$ angles are found in Fig. 4. A rather broad peak spanning $2 \theta$ angle range of $18-30^{\circ}$ which is characteristic of amorphous structures as observed by Ikram et al. [19]. In contrast to this observation, crystalline silica in RHA was found by Armesto et al. [25] in their studies of the combustion behaviour and the characteristics of RHA produced in a bubbling fluidized bed reactor at comparative combustion temperature range $\left(840-880{ }^{\circ} \mathrm{C}\right)$ as used in this study. The group collected RHA samples from bottom of the combustor, baghouse and cyclones but only found the ash collected in the cyclones to be primary amorphous. Their studies in comparison to this work emphasize the need for controlling the temperature and time during combustion of rice husk in order to generate amorphous silica. This enables safe handling and minimizing health hazards associated with crystalline silica. Amorphous characteristic of the silica is also desirable where high reactivity of the material is a necessary pre-requisite for the production of silicon.

\section{Fig. 4}

\subsection{Effect of initial charge composition on phases in reduction product}

Typical phases present in the $\mathrm{Mg}-\mathrm{SiO}_{2}$ (RHA) reaction product are identified by $\mathrm{X}$-ray diffraction analysis as shown Fig. 5. It is observed that magnesium oxide $(\mathrm{MgO})$, magnesium silicide $\left(\mathrm{Mg}_{2} \mathrm{Si}\right)$ and magnesium orthosilicate $\left(\mathrm{Mg}_{2} \mathrm{SiO}_{4}\right)$ are the main by-products of reactions. The relative amounts of these phases in the reaction product will ultimately influence the yield of silicon from the reduction process hence the need to evaluate the effect of initial charge composition that minimizes the formation of these by-product phases. Fig. 6 shows the effect of $\mathrm{Mg} / \mathrm{SiO}_{2}$ mole ratio on the weight 
percent silicon yield from the reduction process. The percent silicon yield is calculated as the ratio of elemental silicon content in the reduction product to the silicon content in the initial silica of the charge. It is seen that the silicon recovery in the reduction samples goes through a maximum at $\mathrm{Mg} / \mathrm{SiO}_{2}$ mole ratio of 2.1 which correspond to a charge with $5 \%$ excess magnesium. This is because at lower ratios, the reduction of silica is incomplete while at the higher ratios, silicon is consumed by the excess magnesium to produce $\mathrm{Mg}_{2} \mathrm{Si}$.

\section{Fig. 5}

\section{Fig. 6}

Evaluation of the effect of temperature (Fig. 7) shows that for a charge with fixed composition, $\mathrm{Mg}_{2} \mathrm{Si}$ phase decreases with increasing temperature whilst the silicon yield increases appreciably with increasing temperature, reaching $85 \%$ for a reduction temperature of $900{ }^{\circ} \mathrm{C}$. A detailed discussion of the reduction behaviour of rice husk ash with magnesium has been published elsewhere by the authors [26].

\section{Fig. 7}

\subsection{Effectiveness of leaching reagent type for post reduction purification}

The reduction product is a mix of silicon and magnesium oxide, silicides and silicates. Silicon's unique property of resisting most acid attacks makes it convenient to separate it from the unwanted byproducts by acid leaching. However, the selectivity of the acid towards the phases present in the reduction product is essential to achieving good silicon recovery and purity. The first leaching stage was therefore intended to remove mainly magnesium oxide $(\mathrm{MgO})$ and other acid soluble components. This should provide a silicon concentrate from which the second stage leaching will focus on removal of silicates and other impurities still present. Table 4 summarises the different reagent compositions that were tested to achieve this objective. The most effective reagent mix was to be selected based on evidence that for fixed weight and composition of the reduction sample, the reagent-mix is able to dissolve the most $\mathrm{MgO}$ measured in terms of $\mathrm{Mg}^{2+}$ aq. assuming all other conditions(temperature and time) remain constant.

A plot of the concentration of magnesium ions in aliquot samples taken over a period of time and at an average leaching temperature $35^{\circ} \mathrm{C}$ is shown in Fig. 8. It is seen that reagent type I \& III which were combined acids offered a better dissolution of the $\mathrm{Mg}$ than the reagents types II and IV which are single acids. It is further observed that the combined acid having the lowest effective concentration (Reagent type-I) had the most dissolving power under the conditions of these tests. It was therefore 
selected as the preferred reagent for first stage post reduction leaching. The second stage leaching was formulated along the same composition but with the hydrochloric acid replaced with hydrofluoric acid.

\section{Fig. 8}

A photograph of final silicon material obtained from this process is shown in Fig. 9a. The silicon material had a brownish appearance with a taint of grey and mean particle size of approximately $18 \mu \mathrm{m}$. A photograph of the silicon chunks obtained after compacting and melting of the silicon powders is shown in Fig. 9. An X-ray difractogram of the as-produced silicon shown in Fig. 9Fig. 10. It can be seen that prominent reflections of crystalline silicon match those of pure silicon. The unmarked peak immediately before the first silicon reflection in Fig.10 is indicative of residual silica possibly resulting from reoxidation of the fine powdered silicon surface. In a test melting of the pelletized silicon powder it was found that the residual silica formed a brownish glassy slag that sit atop the molten silicon. For most practical applications, silicon is melted before use thus the presence of residual silica due to surface oxidation or incomplete digestion can be readily removed during subsequent melting and refining stage.

\section{Fig. 9}

\section{Fig. 10}

The purity of two batches of silicon produced by this process is presented in Table 6 and compared to the plasma refined upgraded metallurgical grade silicon (UMG-Si) used in a directional solidification (DS) process.

\section{Table 6- Comparison of chemical composition of as produced rice husk silicon to industry silicon composition}

It is seen from Table 6 that the dopant impurities (B, P) in the rice husk silicon (RH-Si) are comparable to the plasma refined UMG-Si used in direction solidification process to produce multi crystalline ingot for wafering. The relatively higher aluminum (Al) content in the as-produced $\mathrm{RH}-\mathrm{Si}$ was due to accidental contamination from alumina ware used in milling the sample..

\section{Summary and conclusions}

The feasibility of using rice husk as a renewable source of $\mathrm{CO}_{2}$-neutral energy and also starting material for generation of silicon was demonstrated. A materials and energy balance on the rice husk combustion using TORBED technology indicates the power generation of 1 MWe for a throughput of 1 tonne per hour rice husk. Combustion of rice husk at $850{ }^{\circ} \mathrm{C}$ in TORBED reactor produces a silica-rich ash that is suitable for production of high purity silicon due to amorphous structure of silica, large surface area, and low impurity content. The processing steps and optimum conditions for producing 
silicon from RHA include: primary leaching $\left(10 \% \mathrm{HCl}\right.$ solution, $90{ }^{\circ} \mathrm{C}, 4$ hours), roasting in air $\left(700{ }^{\circ} \mathrm{C}\right.$, 1 hour), reduction by magnesium $\left(\mathrm{Mg} / \mathrm{SiO}_{2}\right.$ mol ratio of 2.1 , temperature $\left.900{ }^{\circ} \mathrm{C}\right)$, and silicon recovery by leaching (two steps; $\mathrm{HCl}+\mathrm{CH}_{3} \mathrm{COOH}$ and $\mathrm{HF}+\mathrm{CH}_{3} \mathrm{COOH}$ ). The produced silicon has an overall purity of over $99.3 \%$ with major impurities being those metals that are more reactive than silicon. Although the produced silicon may not readily meet solar grade requirement but is of much higher purity than metallurgical grade silicon. The product may be used as a high quality feedstock for PV silicon, by including additional refining steps.

\section{Acknowledgment}

The silicon recovery part of this study was co-funded by Process Research Ortech Inc. and Ontario Centres of Excellence.

\section{References}

[1] Swanson RM (2006) A vision for crystalline silicon photovoltaics. Prog. Photovoltaics Res. Appl. 14:443-53.

[2] Chauhan S (2010) Biomass resources assessment for power generation: a case study from Haryana state, India. Biomass Bioenergy 34:1300-8.

[3] Kapur T, Kandpal TC, Garg HP (1996) Electricity generation from rice husk in Indian rice mills: potential and financial viability. Biomass Bioenergy 10:393-403.

[4] Natarajan E, Nordin A, Rao AN (1998) Overview of combustion and gasification of rice husk in fluidized bed reactors. Biomass Bioenergy 14:533-46.

[5] IRRS (2009) World rice statistics. International Rice Research Institute. http://irri.org/ourscience/targeting-and-policy/world-rice-statistics. Accessed 1 Aug. 2010.

[6] Bronzeoak Ltd. (2003) Rice husk ash market study, pp. 1-70.

[7] Cordeiro G, Toledo Filho R, de Moraes Rego Fairbairn E (2009) Use of ultrafine rice husk ash with high-carbon content as pozzolan in high performance concrete Mater Struct 42:983-92.

[8] Shu J, Lakshmanan VI, Dodson CE (2000) Hydrodynamic study of a toroidal fluidized bed reactor. Chem Eng Process 39:499-506.

[9] Lakshmanan VI, Dodson CE (1998) Innovative gas-solid torbed reactor for the recycling industries. JOM 50:29-31.

[10] Dodson CE (1996) TORBED or not TORBED. Chem Eng 2:13-4. 
[11] Chen TT, Dutrizac JE (2003) Characterization of the calcines produced by the roasting of zinc sulphide concentrates in a TORBED reactor Can Metall Q 42:1-6.

[12] Dodson CE, Laughlin RGW, Lakshmanan VI (1998) Application of TORBED thermal process reactor technology to treat recyclables. Proceedings of Waste Processing and Recycling in Mineral and Metallurgical Industries III, The Metallurgical Society of CIM, Montreal, Canada

[13] Clarke GM (1984) TORBED process - a new technique for mineral processing. Ind Miner 207: $57-59$.

[14] Flint WL (1992) Transport and agglomeration of particulate feedstock during calcination and drying processes in a toroidal fluidized bed. Proceedings of 7th Eng Found Conf Fluid. Brisbane, Australia, pp. 659-666.

[15] Zemnukhova L, Egorov A, Fedorishcheva G, Barinov N, Sokol'nitskaya T, Botsul A (2006) Properties of amorphous silica produced from rice and oat processing waste. Inorg Mater 42:24-9.

[16] Singh R, Dhindaw BK (1978) Production of high purity silicon for use in solar cells. In: De Winter F, Cox M, editors. Sun, Mankind's Future Source of Energy: Proceedings of the International Solar Energy Congress. Pergamon Press, New York, pp. 776-81.

[17] Banerjee HD, Sen S, Acharya HN (1982) Investigations on the production of silicon from rice husks by the magnesium method. J Mater Sci Eng 52:173-9.

[18] Bose DN, Govindacharyulu PA (1984) Progress in solar-grade silicon from rice husk. Pergamon Press, Perth, Australia, pp. 2735-81.

[19] Ikram N, Akhter M (1988) X-ray diffraction analysis of silicon prepared from rice husk ash. J Mater Sci 23:2379-81.

[20] Brunauer S, Emmett PH, Teller E (1938) Adsorption of gases in multimolecular layers. J Am Chem Soc 60:309-19.

[21] Madsen IC, Finney RJ, Flann RCA, Frost MT, Wilson BW (1991) Quantitative analysis of high-alumina refractories using X-ray powder diffraction data and the Rietveld method. $\mathrm{J}$ Am Ceram Soc 74:619-24.

[22] Bish DL, Howard SA (1988) Quantitative phase analysis using the Rietveld method. J Appl Crystallogr 21:86-91.

[23] Cox DE, Young RA (1994) The Rietveld method (IUCr Monograph on Crystallography, No. 5), Oxford University Press, UK, pp. 440-441

[24] Houston DF (1972), Rice: chemistry and technology, American Association of Cereal Chemists, St. Paul, USA 
[25] Armesto L, Bahilloa A, Veijonen K, Cabanillasa A, Otero J (2002) Combustion behaviour of rice husk in a bubbling fluidized bed reactor. Biomass Bioenergy 23:171-178.

[26] Larbi KK, Barati M, McLean A (2011) Reduction behaviour of rice husk ash for preparation of high purity silicon. Can Metall Q 50:341-349.

[27] Sarti D, Einhaus R (2002) Silicon feedstock for the multi-crystalline photovoltaic industry. Sol Energy Mater Sol Cells 72:27-40. 


\section{$\underline{\text { List of Figures }}$}

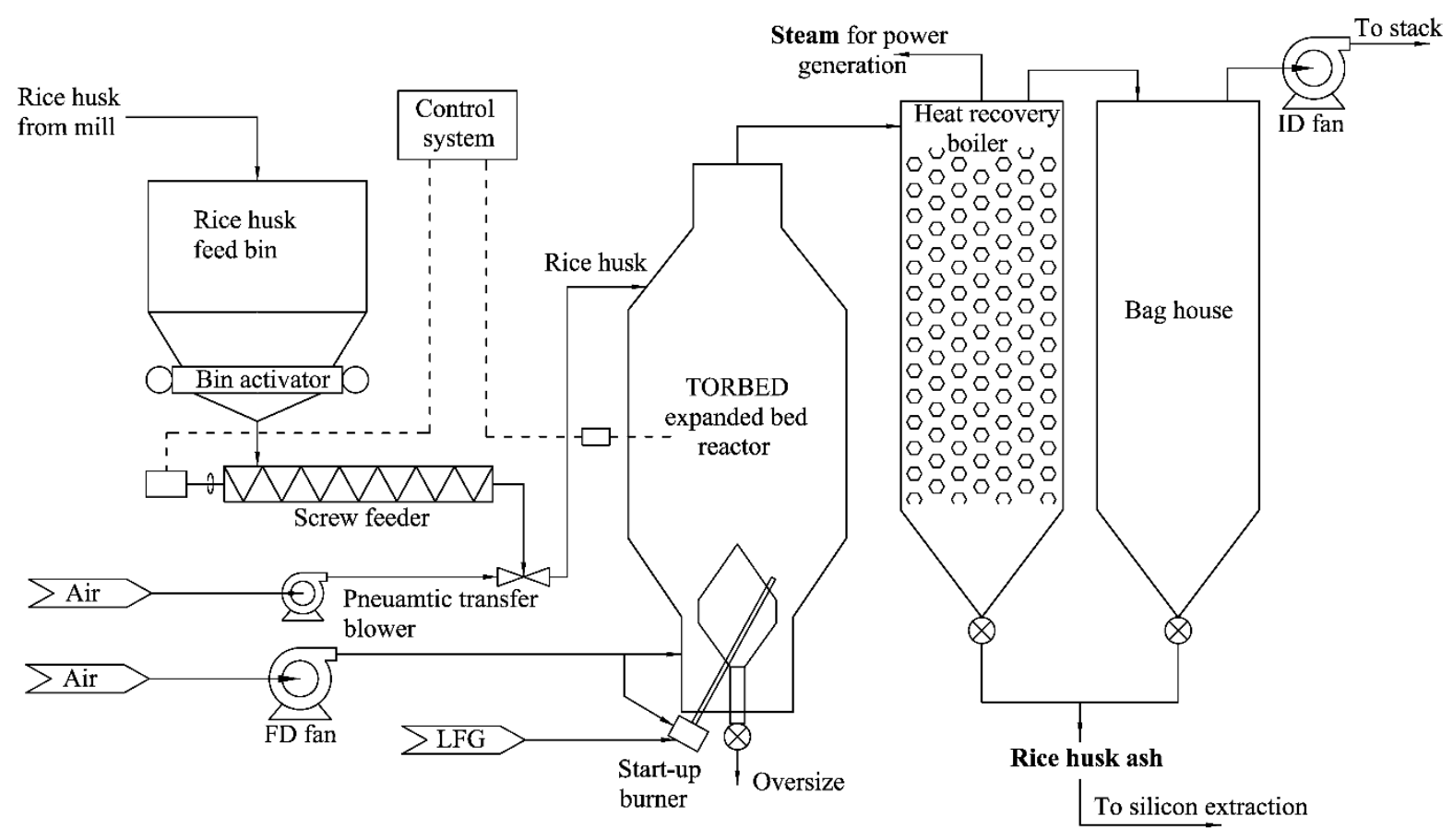

Fig. 1- Process Flow Diagram for rice husk (hull) combustion 


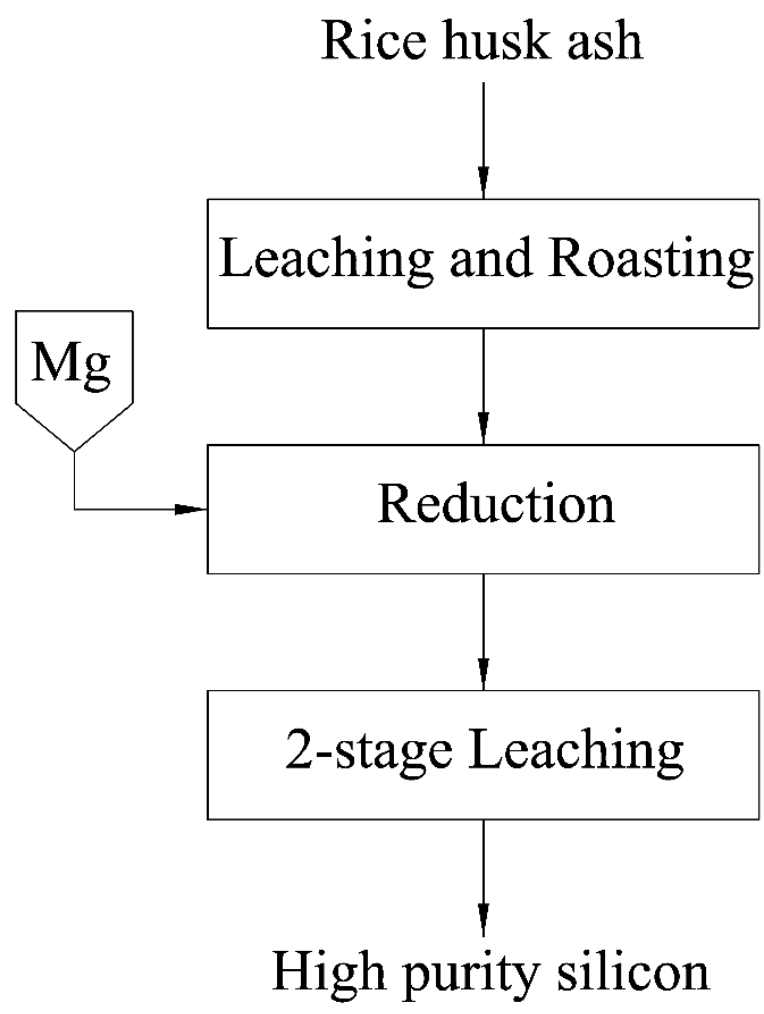

Fig. 2-Scheme of experimental approach.

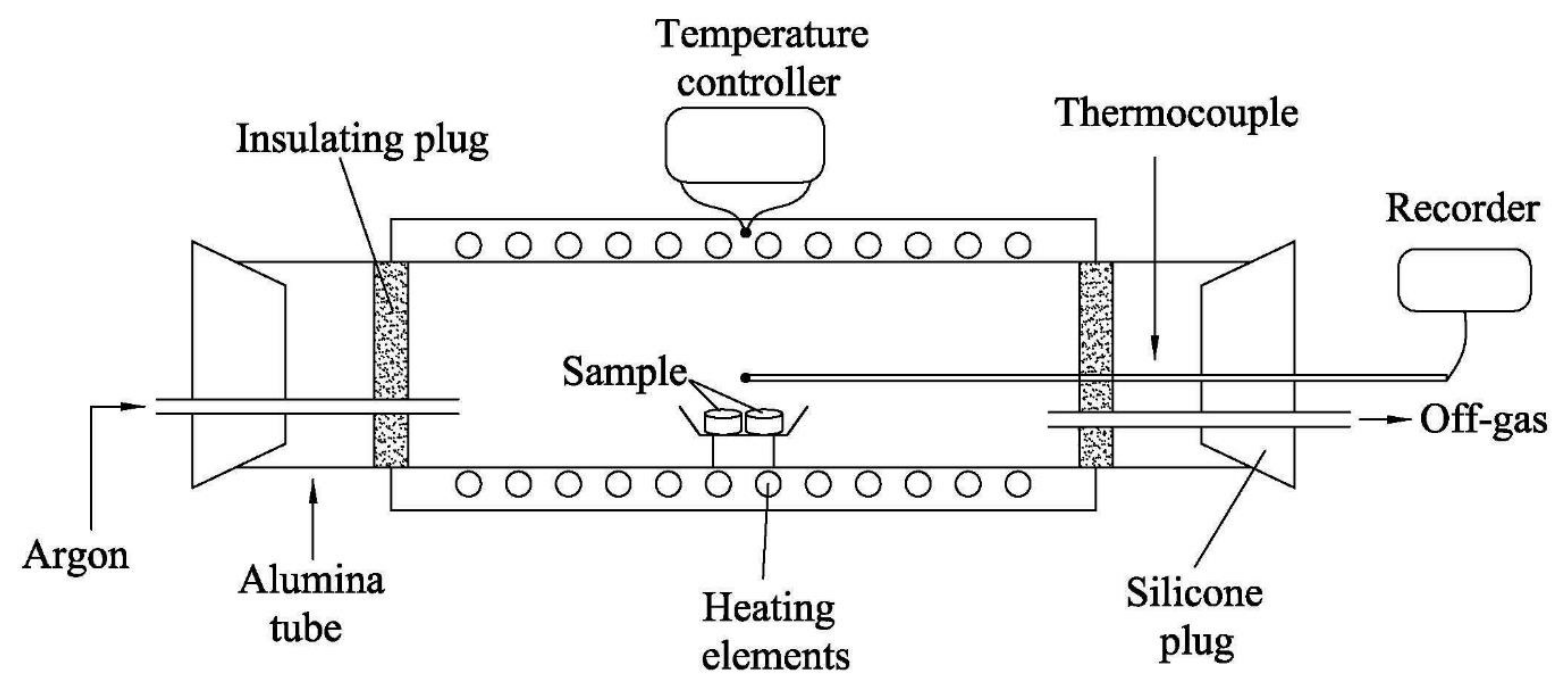

Fig. 3- Schematic of reduction facility 


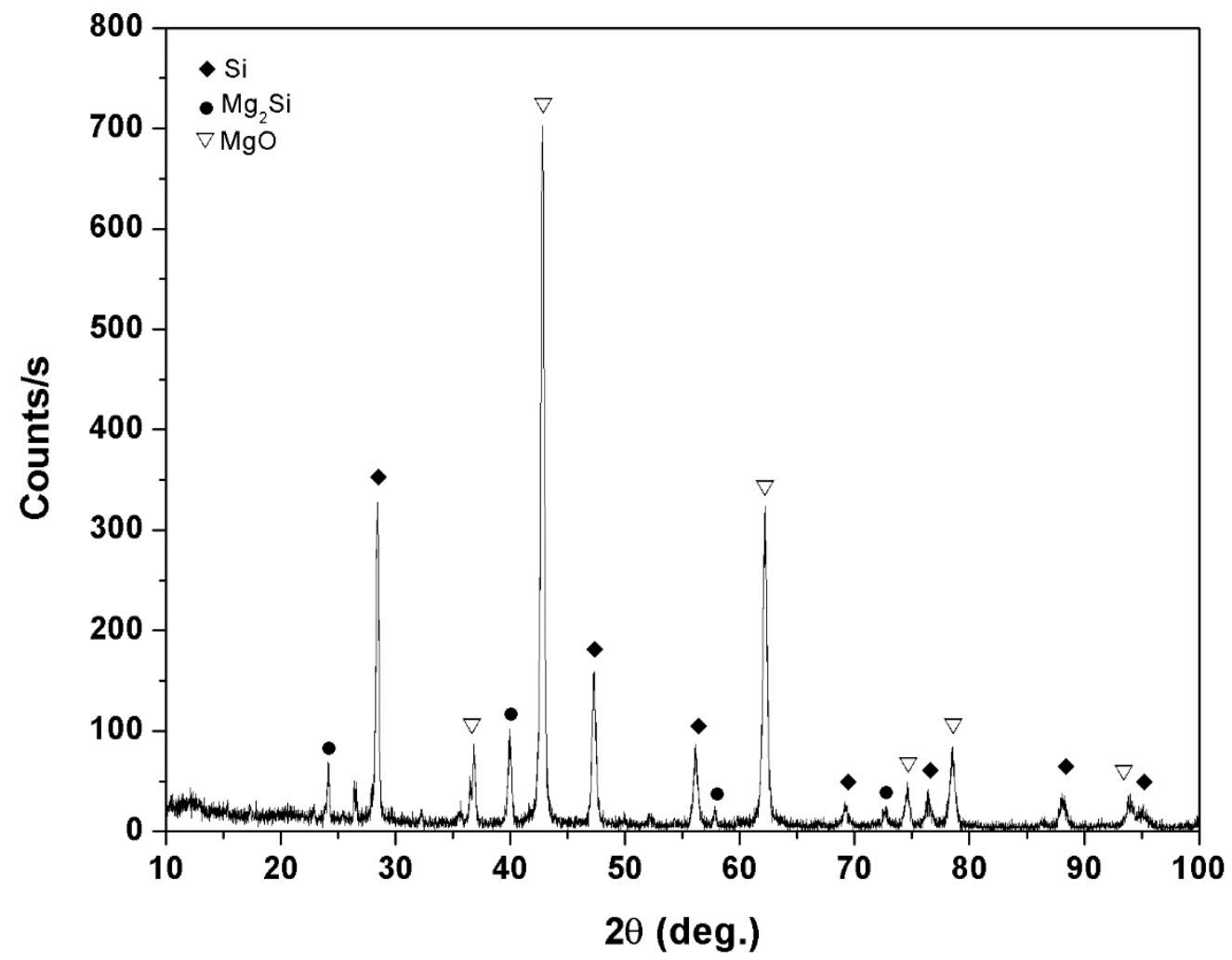

Fig. 4-X-ray diffractogram of as-produced RHA

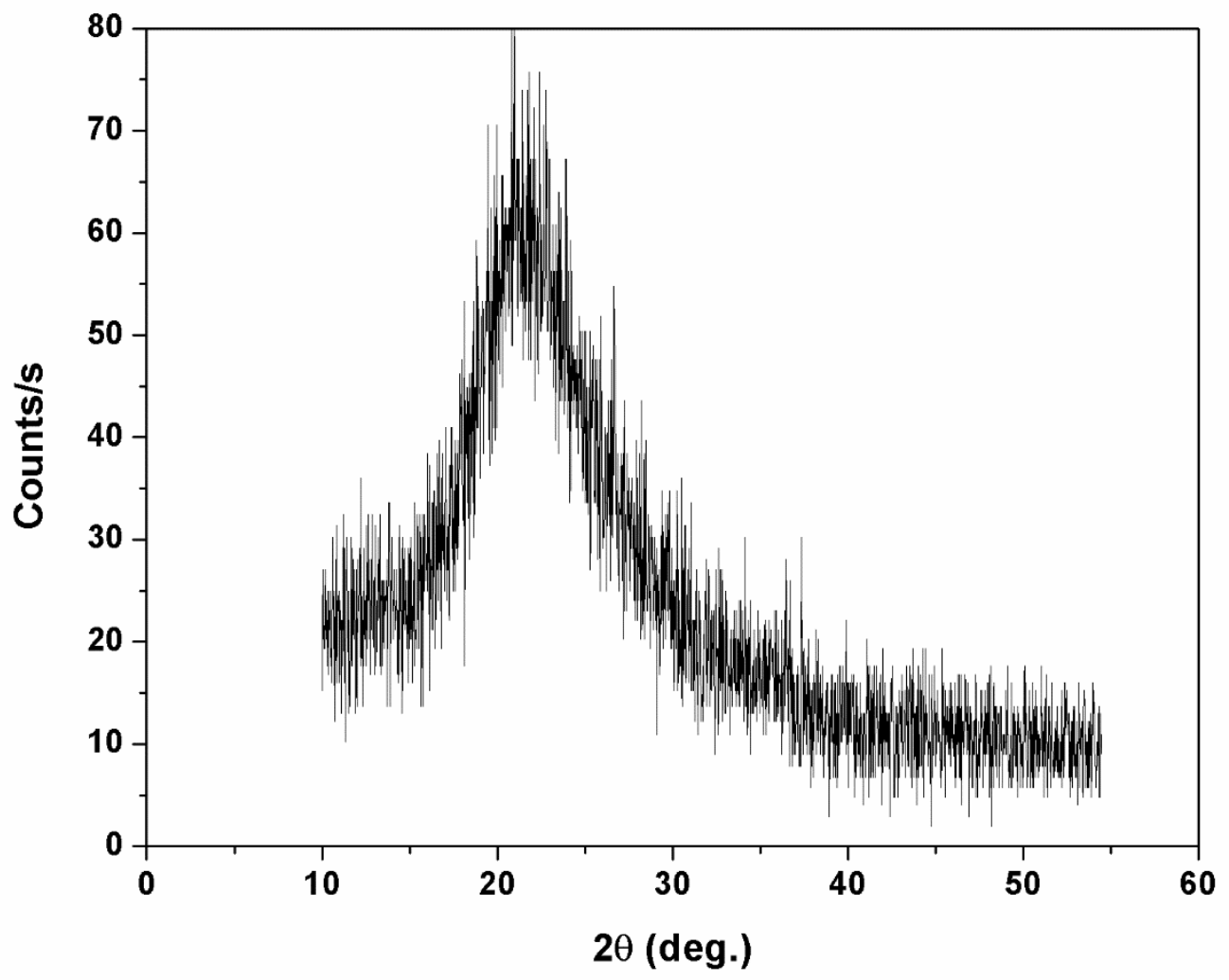


Fig. 5- X- ray diffractogram of reaction product at $800{ }^{\circ} \mathrm{C}$

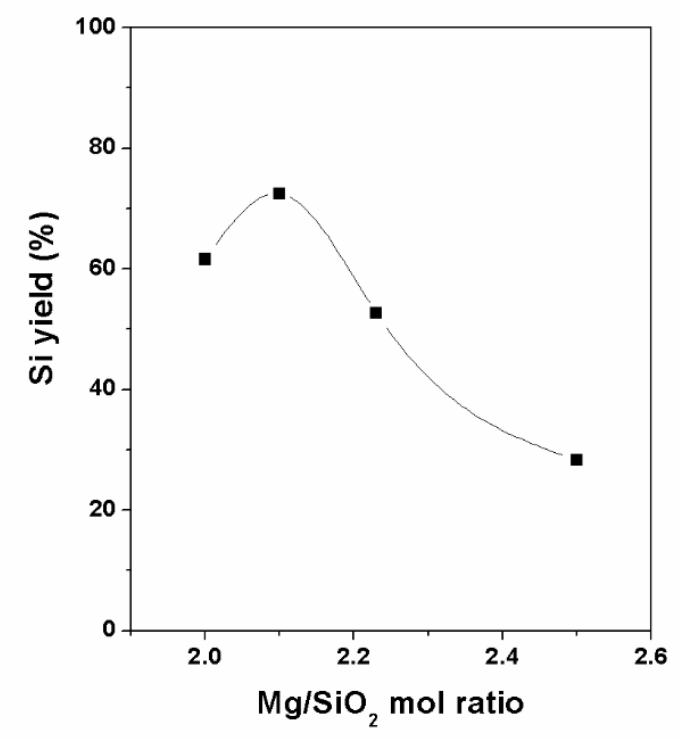

Fig. 6- Effect of $\mathrm{Mg}: \mathrm{SiO}_{2}$ on the silicon yield evaluated experimentally at $650{ }^{\circ} \mathrm{C}$
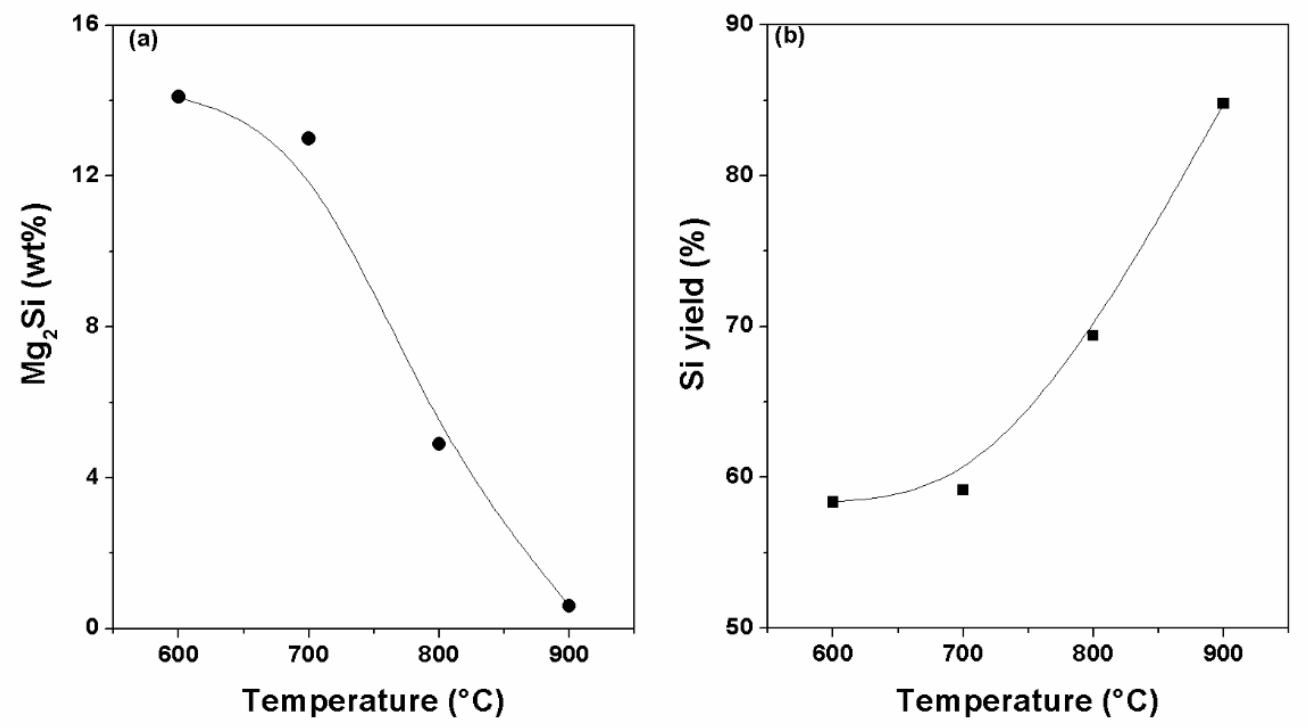

Fig. 7- Experimentally measured effect of temperature on (a) $\mathrm{Mg}_{2} \mathrm{Si}$ formation and (b) Si yield with a charge mix containing $5 \%$ excess magnesium 


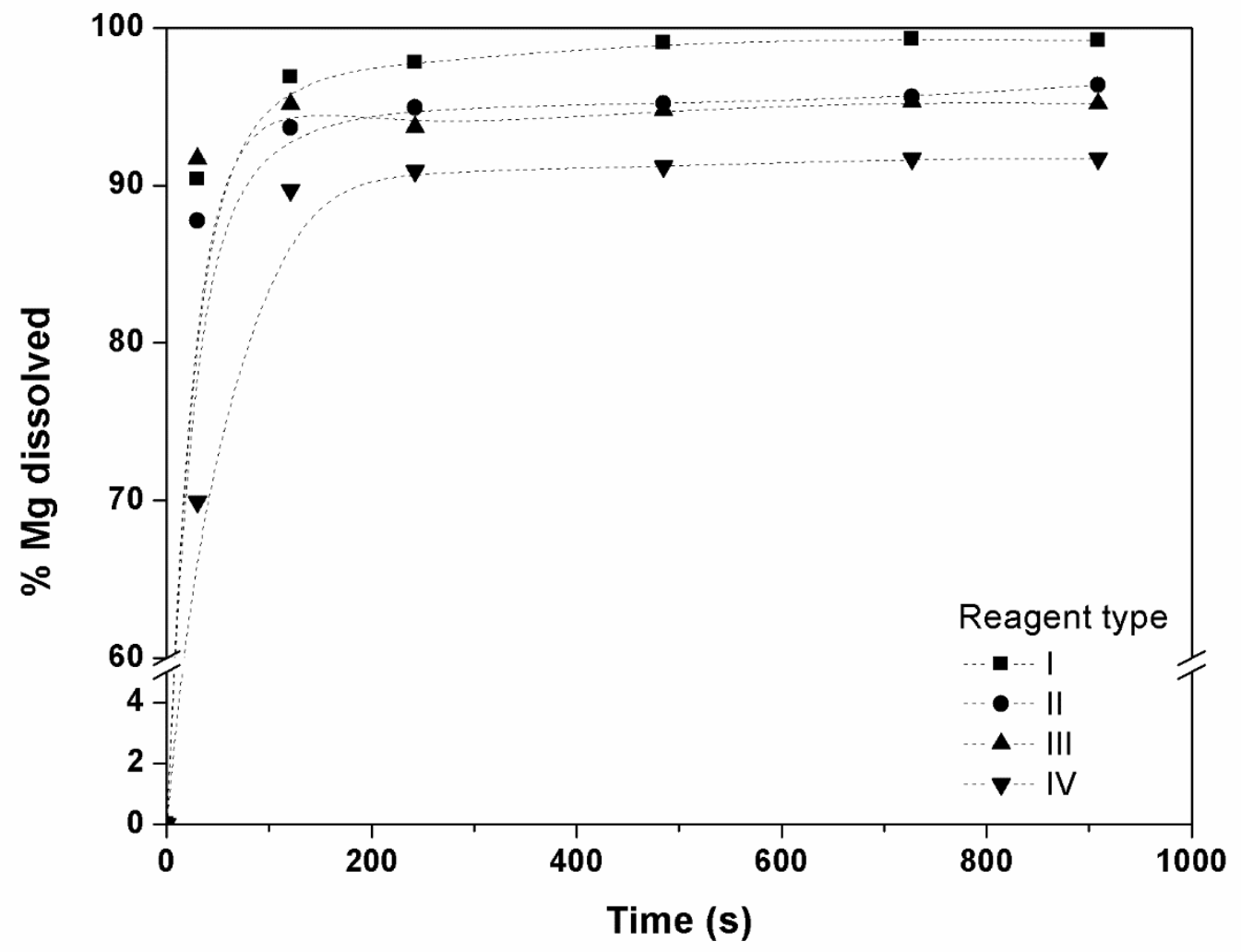

Fig. 8- Effect of reagent type on dissolution of magnesium $(\mathrm{Mg})$ from reduction product
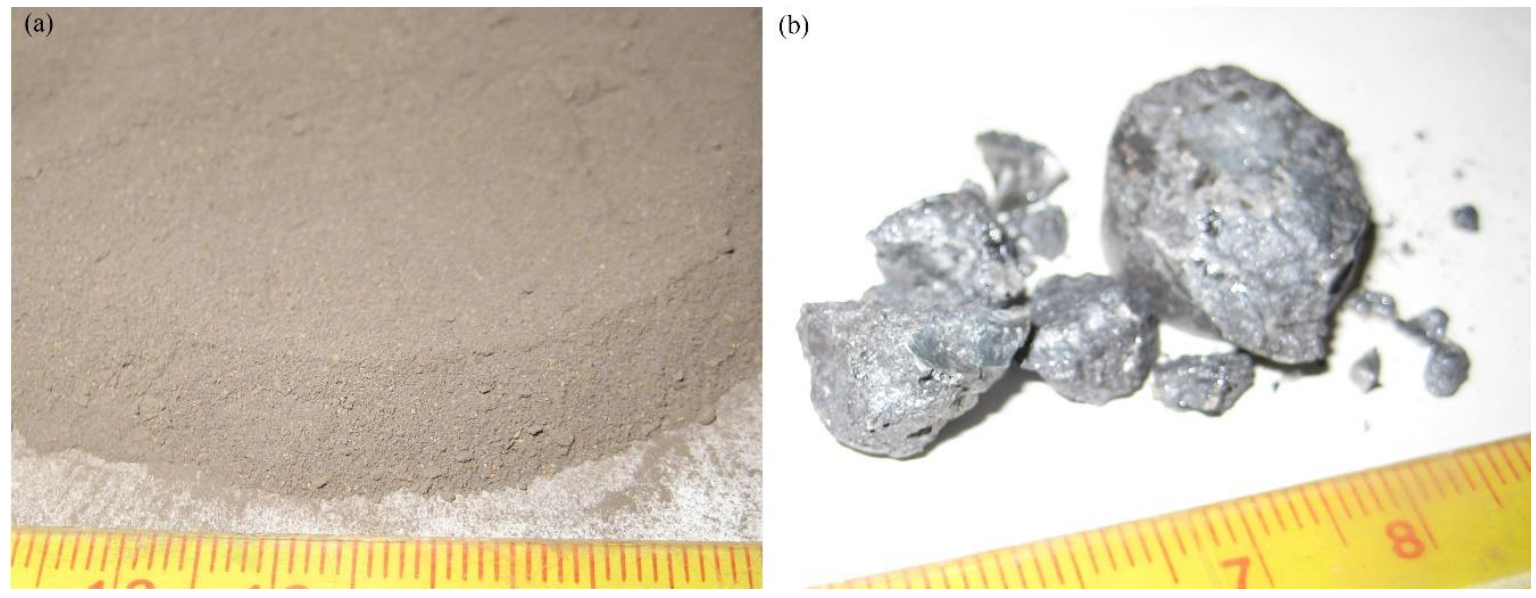

Fig. 9- Photographs of silicon samples: a) as-produced Si powder b) silicon chunks from melting of a) 


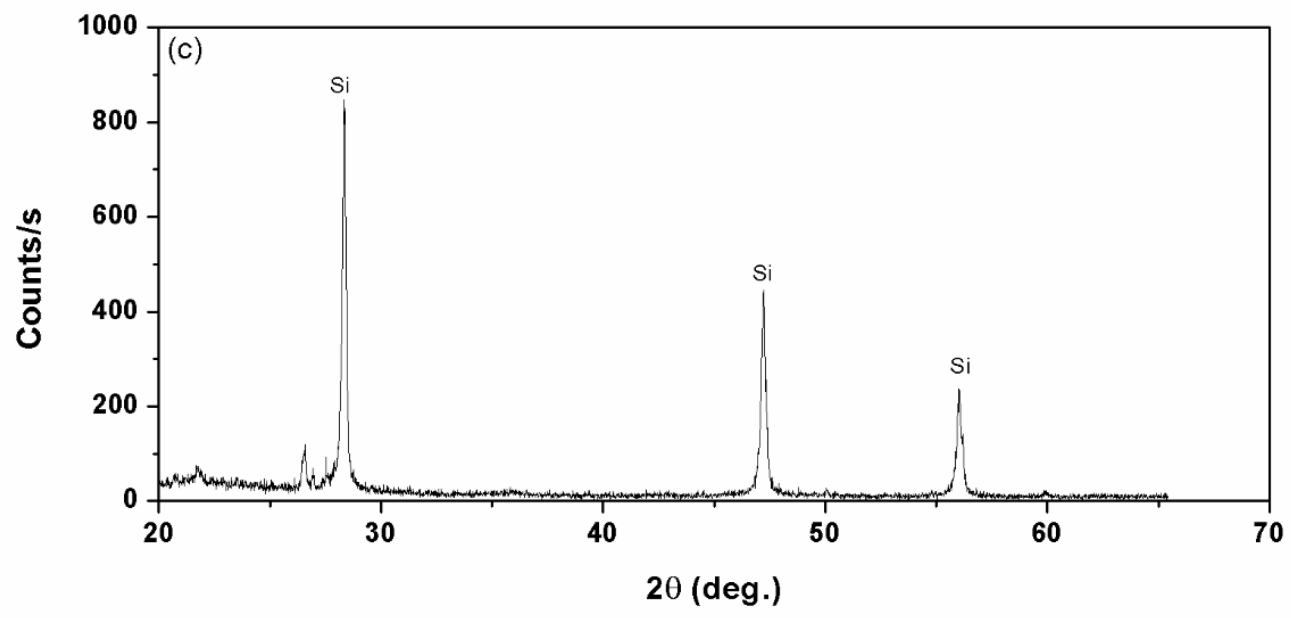

Fig. 10 - X- ray diffractogram of silicon powder as-produced

\section{List of Tables}

Table 1- Ultimate analysis of rice husk

\begin{tabular}{cl}
\hline Composition (\%) & \\
\hline Carbon & 28.08 \\
Hydrogen (total) & 4.89 \\
Nitrogen & 0.68 \\
Sulphur & 0.21 \\
Oxygen & 38.71 \\
Moisture & 8.21 \\
Ash & 19.22 \\
Gross Calorific Value & $13{\mathrm{MJ} . \mathrm{kg}^{-1}}$ \\
\hline
\end{tabular}

Table 2- Mass balance for combustion of one tonne per hour rice husk, in a TORBED reactor

\begin{tabular}{|c|c|c|c|}
\hline \multicolumn{2}{|l|}{ Mass in } & \multicolumn{2}{|l|}{ Mass out } \\
\hline Rice Husk & $1000 \mathrm{~kg} \cdot \mathrm{h}^{-1}$ & $\begin{array}{l}\text { Rice Husk } \\
\text { Ash }\end{array}$ & $180 \mathrm{~kg} \cdot \mathrm{h}^{-1}$ \\
\hline Air & $14,476 \mathrm{~kg} \cdot \mathrm{h}^{-1}$ & Exhaust gas & $15,296 \mathrm{~kg} \cdot \mathrm{h}^{-1}$ \\
\hline Total & $15,476 \mathrm{~kg} \cdot \mathrm{h}^{-1}$ & Total & $15,476 \mathrm{~kg} \cdot \mathrm{h}^{-1}$ \\
\hline
\end{tabular}

Table 3- Exhaust gas composition and flowrate 


\begin{tabular}{lllll}
\hline Component & $\begin{array}{l}\text { Molecular } \\
\text { weight } \\
\text { kg(kmol) }\end{array}$ & $\begin{array}{l}\mathbf{- 1} \\
\text { Mass } \\
\text { Flow } \\
\left(\mathbf{k g . h} \mathbf{h}^{-1}\right)\end{array}$ & Flowrate & Composition \\
$\left(\mathbf{m}^{\mathbf{3}} \cdot \mathbf{h}^{\mathbf{1}}\right)$ & $(\boldsymbol{\%})$ \\
\hline $\mathrm{H}_{2} \mathrm{O}$ & 18 & 491 & 655 & 5.1 \\
$\mathrm{~N}_{2}$ & 28 & 11,147 & 9,555 & 75.2 \\
$\mathrm{O}_{2}$ & 32 & 2,452 & 1,839 & 14.5 \\
$\mathrm{CO}_{2}$ & 44 & 1,206 & 658 & 5.2 \\
Total & & 15,296 & 12,707 & 100 \\
\hline
\end{tabular}

Table 4- Leaching reagent type and effective $[\mathrm{H}+]$ concentration for first stage post reduction leaching

\begin{tabular}{|c|c|c|c|c|c|}
\hline $\begin{array}{l}\text { Reagent } \\
\text { Type }\end{array}$ & $\begin{array}{l}{[\mathrm{HCl}]} \\
\left(\mathrm{mol} . \mathrm{L}^{-1}\right)\end{array}$ & $\begin{array}{c}\text { Volume } \\
\%\end{array}$ & $\begin{array}{c}{\left[\mathrm{CH}_{3} \mathrm{COOH}\right]} \\
\left(\mathrm{mol} . \mathrm{L}^{-1}\right)\end{array}$ & $\begin{array}{c}\text { Volume } \\
\%\end{array}$ & $\begin{array}{l}\text { Effective }\left[\mathrm{H}^{+}\right] \\
\left(\mathrm{mol} . \mathrm{L}^{-1}\right)\end{array}$ \\
\hline I & 1.25 & 80.0 & 4.38 & 20.0 & 1.00 \\
\hline II & 1.25 & 100.0 & 0.00 & 0.0 & 1.25 \\
\hline III & 4.00 & 80.0 & 4.38 & 20.0 & 3.20 \\
\hline IV & 4.00 & 100.0 & 0.00 & 0.0 & 4.00 \\
\hline
\end{tabular}

Table 5- Characteristics of as-received and purified RHA samples

\begin{tabular}{lll}
\hline & $\mathrm{I}$ & $\mathrm{II}$ \\
\hline Mean Particle size $(\mu \mathrm{m})$ & 35 & $\mathrm{n} / \mathrm{a}$ \\
BET Specific Surface Area $\left(\mathrm{m}^{2} \cdot \mathrm{g}^{-1}\right)$ & 39.3 & 34.6 \\
Chemical Composition $(\%)$ & & \\
$\mathrm{B}$ & $5.1 \times 10^{-3}$ & $<2 \times 10^{-4}$ \\
$\mathrm{P}$ & 0.16 & $3.4 \times 10^{-2}$ \\
$\mathrm{SiO}_{2}$ & 91.5 & 98.4 \\
$\mathrm{Al}_{2} \mathrm{O}_{3}$ & 0.62 & 0.42 \\
$\mathrm{MgO}_{\mathrm{Fe}} \mathrm{O}_{3}$ & 0.30 & 0.12 \\
$\mathrm{CaO}$ & 0.57 & 0.12 \\
$\mathrm{MnO}$ & 0.39 & 0.12 \\
$\mathrm{C}($ LECO analysis) & 0.04 & 0.03 \\
L.O.I & 1.87 & 0.13 \\
& 3.05 & 0.60 \\
\hline
\end{tabular}


Table 6- Comparison of impurity levels in as produced rice husk silicon to plasma refined upgraded metallurgical grade silicon (p-UMG-Si) used in Directional Solidification (DS) [27]

\begin{tabular}{|c|c|c|c|c|c|c|}
\hline & \multicolumn{6}{|c|}{ Chemical Composition (ppmw) } \\
\hline & \multirow[b]{2}{*}{$\begin{array}{l}\mathrm{Si} \\
(\%)\end{array}$} & \multicolumn{5}{|c|}{$\operatorname{Impurity} \operatorname{MAX}(\leq)$} \\
\hline & & B & $\mathrm{Al}$ & $\mathrm{P}$ & $\mathrm{Fe}$ & $\mathrm{Ca}$ \\
\hline $\begin{array}{l}\text { p-UMG-Si for DS [Sarti } \\
\& \text { Einhaus, 2002] }\end{array}$ & $\mathrm{n} / \mathrm{a}$ & 20 & 90 & 30 & 90 & 450 \\
\hline Batch 1 & $99.5^{*}$ & 3 & 1300 & 72 & 700 & 300 \\
\hline Batch 2 & $99.3^{*}$ & 18 & 1600 & 25 & 500 & 700 \\
\hline
\end{tabular}

